\title{
Experimental Infection of Local Domestic and Feral (Columba livia domestica) Pigeons with Local Isolate of H9N2 Influenza Virus: Virological and Histopathological Study
}

\author{
Ahmed Raad Rasheed ${ }^{1}$, Karim Sadun Al-Ajeeli ${ }^{2}$ and Amer Khazaal Al-Azawy ${ }^{2 *}$ \\ ${ }^{I}$ Department of Animal Production, Directorate of Animal Resource, Ministry of Agriculture, Iraq \\ ${ }^{2}$ Department of Microbiology, College of Veterinary Medicine, University of Diyala, Iraq \\ *Corresponding author's Email: amer_alazawy@yahoo.com; ORCID: 0000-0002-4422-5442
}

\begin{abstract}
A local isolate of low pathogenic Avian Influenza Virus (AIV) H9N2 subtype was used in experimental infection of 50 domestic and 50 feral pigeons (Columba livia domestica) to determine the susceptibility of these birds to H9N2 infections and to study its histopathological effects on vaccinated and unvaccinated pigeons with H9N2 commercial vaccine. The birds were divided into five groups. Groups A and C contained 20 feral pigeons, B and D contained 20 domesticated pigeons. Group E contained 10 feral and 10 domesticated pigeons that were used as unvaccinated controls. Groups A and B were vaccinated with H9N2 and Newcastle disease virus commercial vaccines. Group C and D were vaccinated with Newcastle disease virus vaccine only. All groups except E were challenged with a local isolate of H9N2 serotype. Antibodies titers against AIV were estimated pre and post-vaccination using ELISA. The results indicated low antibody titers against AIV in all groups in pre-vaccination that ranged between $152.83 \pm 42.01$ and $337.00 \pm 150.76$ with no significant differences between groups. Post-vaccination antibody evaluation indicated high titers of anti-AIV antibodies in groups A and B (740.13 \pm 214.38 and $673.00 \pm 242.40$, respectively) in comparison to pre-vaccination levels. Clinical signs appeared on $5^{\text {th }}$ day post-vaccination that included mild respiratory signs, digestive disorders, and conjunctivitis in some birds of all groups. Histopathological changes in affected tissues appeared as moderate to severe multifocal necrosis diffused in the parenchymal cells of lung tissues. Infiltration with mononuclear inflammatory cells was detected in some lung tissue areas. Necrotic foci and mononuclear cell infiltration were also observed in trachea and liver of infected pigeons but mild changes were observed in intestine. The challenge virus was re-isolated in embryonated hen's eggs of nine days old by inoculation in allantoic cavity using samples collected from tissues and cloaca of infected pigeons showing clear clinical signs. The re-isolated virus was detected by the haemagglutination test using chicken RBCs and identified by haemagglutination inhibition test using a locally prepared hyperimmune serum to H9N2 in rabbits. In conclusion, pigeons are susceptible to AIV (H9N2) that might facilitate the transmission of the virus to other bird species.
\end{abstract}

Key words: Avian Influenza viruses, H9N2, Pigeons

\section{INTRODUCTION}

Avian Influenza Viruses (AIVs) spread widely in birds worldwide; they are contagious but variable in their virulence. Accordingly, they were subdivided into Low Pathogenic AIV (LPAIV) and High Pathogenic AIV (HPAIV) (Imai et al., 2013). The domesticated birds and mammalian are susceptible to AIV and aquatic birds are natural virus reservoirs. AIV infections might cause severe disease in poultry with a mortality rate of more than $90 \%$, mostly associated with HPAIV strains (MacLachlan and Dubovi, 2011).

Influenza A viruses based on genetic and antigenic differences in hemagglutinin (HA) and neuraminidase
(NA) are divided into $17 \mathrm{HA}$ (H1 to H17) and $11 \mathrm{NA}$ (N1 to N11) subtypes (Shehata et al., 2015; Mostafa et al., 2018). All these subtypes are grouped in genus Influenzavirus $A$ which is classified within the family Orthopoxviridae. Genus Influenzavirus A included viruses with linear single-stranded, negative-sense and segmented (eight segments) RNA genome (MacLachlan and Dubovi 2011). Antigenic shift and antigenic drift are the most common processes that continuously change influenza viruses and lead to the emergence of new influenza virus variants or strains (Lee et al., 2016; Kandeil et al., 2017; Arai et al., 2019).

Influenza virus subtype H9N2 is a LPAI virus and the most widespread avian influenza subtype in poultry 
worldwide (Abdelwhab and Abdel-Moneim, 2015; Nagy et al., 2017). In Iraq, H9N2 is endemic since 2004 (Kraidi et al., 2016; Kraidi et al., 2017; Mohamed et al., 2018). This virus has also been reported to cause high mortality rates in broilers (70\%) as well as in breeders and layers up to $10 \%$ (Khamas, 2008).

Feral and domestic pigeons are found worldwide and can easily cross borders like the wild aquatic birds, and sometimes live close to these aquatic birds. Many reports have mentioned that wild aquatic and domestic birds are reservoirs for influenza A viruses (Abdelwhab and AbdelMoneim, 2015; Nagy et al., 2017; Kausar et al., 2018). The possibility of transmission of such viruses to pigeons is acceptable as many studies have reported the natural infection of pigeons with the H9N2 influenza virus (Gomaa et al., 2015; Xu et al., 2015; Kandeil et al., 2017; Kausar et al., 2018; Tolba et al., 2018). No data on the isolation of H9N2 from pigeons or experimental infection of pigeons with H9N2 is available in Iraq. Accordingly, the present study aimed to determine the susceptibility of wild and domestic pigeons to the experimental infection with a local isolate of H9N2 LPAIV and to study the efficacy of H9N2 commercial vaccine in pigeons.

\section{MATERIALS AND METHODS}

\section{Ethical approval}

Scientific Ethical Committee in the University of Diyala/ Iraq, approved the research and give the ethical number (Vet 14 Medicine November 2018 A and K).

\section{Study design}

This cross-sectional study was conducted in Diyala province, Iraq, over the period from September 2018 to June 2019. In this study, 100 local domestic and feral pigeons (Columba livia domestica) were used and divided into five groups (A, B, C, D and E) as presented in table 1 . All groups were isolated from each other in separated and completely closed animal houses to avoid any contact between them by any means of sharing feed, water, utensil, workers and environment.

Table 1. Pigeon groups used in the present study

\begin{tabular}{llll}
\hline Group & Type of birds of birds & Number & Treatment \\
\hline A & Wild pigeons & 20 & Vaccinated with H9N2 and NDV* \\
B & Domestic pigeons & 20 & Vaccinated with H9N2 and NDV* \\
C & Wild pigeons & 20 & Vaccinated with NDV** \\
D & Domestic pigeons & 20 & Vaccinated with NDV** \\
E & Wild and Domestic pigeons & $20(10$ for each type $)$ & Control unvaccinated group \\
\hline
\end{tabular}

NDV: Newcastle disease virus, *H9N2-NDV commercial vaccine (Nobilis ${ }^{\circledR}$, MSD Company, Netherlands), **NDV (MSD, LaSota, Netherlands)

\section{Detection of pre-vaccination antibodies against avian influenza virus}

Avian influenza virus antibodies were measured in all groups by using ELISA kit (Zoetis proFLOK ${ }^{\mathrm{TM}}$, avian influenza virus antibody test kit, item MI 49007, USA). Accordingly, blood samples were collected from wing veins of pigeons, then the sera were separated, labeled and subjected to the ELISA test according to the manufacturer's instruction.

\section{Vaccination of pigeons}

Groups A and B were vaccinated with inactivated Newcastle Disease Virus (NDV) and influenza H9N2 inactivated vaccine (Nobilis®, MSD Company, Netherlands) by subcutaneous route (The birds are of different ages). Group $\mathrm{C}$ and $\mathrm{D}$ were vaccinated with the NDV vaccine (MSD, LaSota, Netherlands) by drinking water. This was done by fasting of pigeons from water for
24 hours and then they were supplemented with distilled water containing the LaSota NDV vaccine.

\section{Detection of post-vaccination antibodies against avian influenza virus}

Blood samples were collected after 7 days postvaccination from vaccinated groups with influenza H9N2 vaccine to determine anti-AIV antibodies. For this purpose, ELISA was performed using the AIV ELISA kit (Zoetis proFLOK ${ }^{\mathrm{TM}}$, avian influenza virus antibodies kititem MI 49007, USA) according to the instruction manual of the manufacturer.

\section{Challenge virus}

Influenza virus (H9N2) registered in National Center for Biotechnology Information NCBI with accession number (MH368755.1) was kindly provided by Mohammed Abdulkadhim Hussein and Prof. Dr. Emad J. 
Khammas from College of Veterinary Medicine, University of Baghdad.

The stock virus $(0.1 \mathrm{ml})$ was inoculated into the allantoic cavity of nine-day-old embryonated hen's eggs. The inoculation site was sealed with wax and inoculated eggs were incubated at $37{ }^{\circ} \mathrm{C}$ and observed daily for the death of the embryo. Eggs with dead embryos were removed from the incubator, chilled in a refrigerator at $4^{\circ} \mathrm{C}$ for a few hours and opened to collect the allantoic fluid. The collected fluid was tested for the presence of H9N2 by slide haemagglutination test using $4 \%$ avian red blood cells in sterile normal saline (Webster et al., 2002). H9N2 positive fluid from embryonated eggs was pooled together, labeled and kept frozen at $-30{ }^{\circ} \mathrm{C}$ until be used.

\section{Titration of stock virus}

Propagated H9N2 was titrated in two ways, using HA and $50 \%$ Embryo Infectious Dose $\left(\mathrm{EID}_{50}\right)$. Haemagglutination test was performed by 2 -folds serial dilution of the stock virus in sterile Phosphate Buffered Saline (PBS) using 96 well plastic plates and according to the method described by Killian (2008). The viral titers were also determined by $\mathrm{EID}_{50}$ using 10 -folds serial dilutions of the H9N2 stock virus in sterile PBS. Five, nine-day-old embryonated hen's eggs were used for the inoculation of each viral dilution according to the method described by Reed and Muench (1938).

\section{Preparation of hyperimmune serum against influenza virus A (H9N2)}

Hyperimmune serum against subtype H9N2 was prepared in rabbits according to the method described by Horwitz and Scharff (1969). For this purpose, three rabbits were raised for hyperimmune serum preparation and two rabbits were used as control. Blood samples were collected from all rabbits before vaccination, then the serum was separated from each sample in sterile test tubes and frozen at $-30^{\circ} \mathrm{C}$ until use. Each rabbit was intramuscularly inoculated with $1 \mathrm{ml}$ of influenza H9N2 vaccine (Nobilis®, MSD Company, Netherlands) virus. The control rabbits were inoculated with $1 \mathrm{ml}$ of sterile normal saline. This inoculation was repeated weekly for successive three weeks. Blood samples were collected from inoculated rabbits one week after the last inoculation. After coagulation, the serum was separated by cold centrifugation at $3000 \mathrm{rpm}$ for 30 minutes at $4{ }^{\circ} \mathrm{C}$. Clear serum was pooled together and titrated by Haemagglutination Inhibition (HI) test according to the method described by Williams (1980) and kept at $-30^{\circ} \mathrm{C}$ until use.

\section{Challenge of pigeons}

Each pigeon was challenged via a dropping of $0.5 \mathrm{ml}$ $\left(10^{9.5} \mathrm{EID}_{50} / 0.1 \mathrm{ml}\right)$ of the virus into the nose, trachea, and eyes. All the infected pigeons were observed daily for 15 days.

\section{Detection of post-challenge antibodies}

Antibodies against subtype H9N2 were determined on $5^{\text {th }}$ day Post-Infection (PI) using the HI test and ELISA. Accordingly, blood samples were collected from infected birds, then sera were separated and subjected to both HI test (using the plate method and locally prepared H9N2 hyperimmune serum) and ELISA (using the same abovementioned ELISA kit).

\section{Collection and processing of samples from infected pigeons \\ Cloacal swab samples and tissue samples (trachea,} lung, liver, and intestine) were collected from experimentally infected pigeons at days 5, 6, 7, 8, 9 and 10 PI. Each swab sample was placed in a sterile tube containing PBS and centrifuged at $3000 \mathrm{rpm}$ for 20 minutes in a cool centrifuge. Then the supernatant was collected and $0.5 \mathrm{ml}$ of antibiotic- antimycotic and antimycoplasma were added to the sample to eliminate other infectious pathogens. After 30 minutes of incubation at room temperature, the sample was kept frozen at $-30{ }^{\circ} \mathrm{C}$ until use. Tissue samples were divided into two groups. The first group was tested for virus detection by reisolation in embryonated hen's eggs and identification by the HI test. The second group of samples was subjected to histopathological study according to methods described by Durrani et al. (2008) and Bancroft and Gamble (2008). Sections were examined by light microscopy (OlympicJapan) and photomicrographs were taken with a digital camera (Omax, USA) for each section.

\section{Re-isolation of H9N2}

The influenza virus (H9N2) used for pigeons inoculation was re-isolated by the processing of collected tissue and the cloacal swab samples. A $10 \%$ suspension of minced tissue samples collected from challenged pigeons was made in sterile PBS, then $0.1 \mathrm{ml}$ of the suspension was inoculated into the allantoic cavity of three embryonated eggs (9-11 days old), incubated at $37^{\circ} \mathrm{C}$ and processed 3-4 days PI. The processed and collected allantoic fluid of these eggs was pooled and tested for the presence of the virus using slide haemagglutination test and then identified by HI test using the prepared H9N2 hyperimmune serum. 


\section{Statistical analysis}

The data were analyzed using SPSS version 22. A pvalue less than 0.05 was considered significant.

\section{RESULTS}

\section{Pre-vaccination antibodies}

Pre-vaccination antibodies titers against AIV are presented in table 2. Some birds, both feral and domestic pigeons, showed high titers exceeding 600 or 700 units, whereas, in many of birds no antibodies to AIV were found.

\section{Post-vaccination antibodies}

Antibodies titers against influenza virus (H9N2) after the vaccination of groups A and B are presented in table 3 .

\section{Titers of propagated stock influenza virus subtype H9N2}

The titer of propagated stock virus subtype H9N2 measured by the haemagglutination test was 1024 $\mathrm{HAU} / 0.1 \mathrm{ml}$. in addition, the propagated virus titer determined by $50 \%$ embryo infectious dose was $10^{10.5}$ $\mathrm{EID}_{50} / 0.1 \mathrm{ml}$. The virus was re-identified by the use of hyperimmune serum in the HI test and showed an anti-HA antibodies titer of $2048 \mathrm{HIU} / 0.1 \mathrm{ml}$ of stock serum.

\section{Post-challenge antibody immune response}

Antibody titers against AIV in four challenged groups are shown in tables 4 and 5. There was no significant difference in AIV antibody titer between group A and group B, as well as between group $\mathrm{C}$ and group $\mathrm{D}$. While significant differences $(\mathrm{P}<0.05)$ in antibody titers were observed in each of $\mathrm{A}$ and $\mathrm{B}$ groups when compared to each of $\mathrm{C}$ and $\mathrm{D}$ groups. The high titers were found in H9N2 vaccinated and challenged groups.

Table 2. Titers of avian influenza virus antibodies detected by ELISA in the pre-vaccination period

\begin{tabular}{lccc}
\hline Group of pigeon* & $\begin{array}{c}\text { Anti AIV antibodies } \\
\text { (Mean } \pm \text { SE) }\end{array}$ & GMT & \% CV \\
\hline A (wild) & $274.56 \pm 88.05^{\mathrm{a}}$ & 31 & 23.38 \\
B (domestic) & $278.40 \pm 120.45^{\mathrm{a}}$ & 14 & 91.50 \\
C (wild) & $225.60 \pm 114.25^{\mathrm{a}}$ & 9 & $88 . .84$ \\
D (domestic) & $152.83 \pm 42.01^{\mathrm{a}}$ & 13 & 89.25 \\
E (mixed control) & $337.00 \pm 150.76^{\mathrm{a}}$ & 7 & 134.76
\end{tabular}

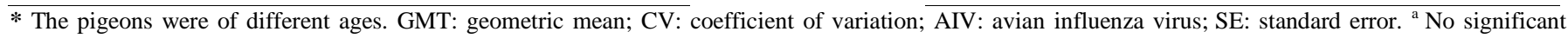
differences $(\mathrm{p}>0.05)$

Table 3. Titers of avian influenza virus antibodies detected by ELISA on 7th day post-vaccination

\begin{tabular}{lcccc} 
Groups* & Number of samples & Mean \pm SE & GMT & CV $(\%)$ \\
\hline A (wild pigeon) & 15 & $740.13 \pm 214.38^{\mathrm{a}}$ & 65 & 86.55 \\
\hline B (domestic pigeon) & 15 & $673.00 \pm 242.40^{\mathrm{a}}$ & 40 & 99.02 \\
\hline
\end{tabular}

${ }^{*}$ The pigeons were of different ages. GMT: geometric mean; CV: coefficient of variation; SE: Standard error. ${ }^{a}$ No significant difference $(\mathrm{p}>0.05)$.

Table 4. Detection of avian influenza virus antibodies by haemagglutination inhibition test in challenged groups of pigeons with avian influenza virus subtype H9N2 at 5 days post-challenge

\begin{tabular}{ccccc}
\hline & \multicolumn{3}{c}{ Groups } \\
\cline { 2 - 5 } & A & B & C & D \\
\hline Mean HI titre* & 256 & 128 & 64 & 64 \\
\hline
\end{tabular}

*Titers were calculated in HI units (HIU)/100 $\mu$ l of serum sample. HI: haemagglutination inhibition

Table 5. Detection of avian influenza virus antibodies by ELISA in challenged groups of pigeons with avian influenza virus subtype H9N2 at 5 days post-challenge

\begin{tabular}{lcccc}
\hline Groups & $\mathbf{N}$ & $\begin{array}{c}\text { Anti AIV antibodies } \\
\text { (Mean } \pm \text { SE) }\end{array}$ & GMT & \%CV \\
\hline A & 15 & $1931.00 \pm 453.24^{\mathrm{a}}$ & 623 & 63.36 \\
B & 18 & $1845.61 \pm 343.94^{\mathrm{a}}$ & 756 & 56.62 \\
C & 18 & $888.11 \pm 163.57^{\mathrm{b}}$ & 219 & 51.12 \\
D & 15 & $955.66 \pm 218.86^{\mathrm{b}}$ & 173 & 63.69 \\
\hline
\end{tabular}

Different superscript letters indicate significant differences $(\mathrm{p}<0.05)$ between groups. SE: Standard error 


\section{Clinical signs}

Clinical signs appeared in pigeons after 5 days PI and no mortality rates were recorded. The clinical signs disappeared at 8 and 10 days PI. Sporadic cases with mild depression were found in groups A and B, also there were two cases with bilateral conjunctivitis in each group (Figures 1A and B). Some birds showed signs of mild respiratory disorders such as nasal discharge and sneezing. Moderate clinical signs of respiratory disorders were observed in many pigeons of group $\mathrm{C}$ and $\mathrm{D}$. One pigeon in group D showed subcutaneous hemorrhage in non-feathered skin of legs (Figure 1C). The clinical signs in groups A, B, and $\mathrm{D}$ disappeared on day $8 \mathrm{PI}$, whereas the clinical signs in group C disappeared on day 9 PI.
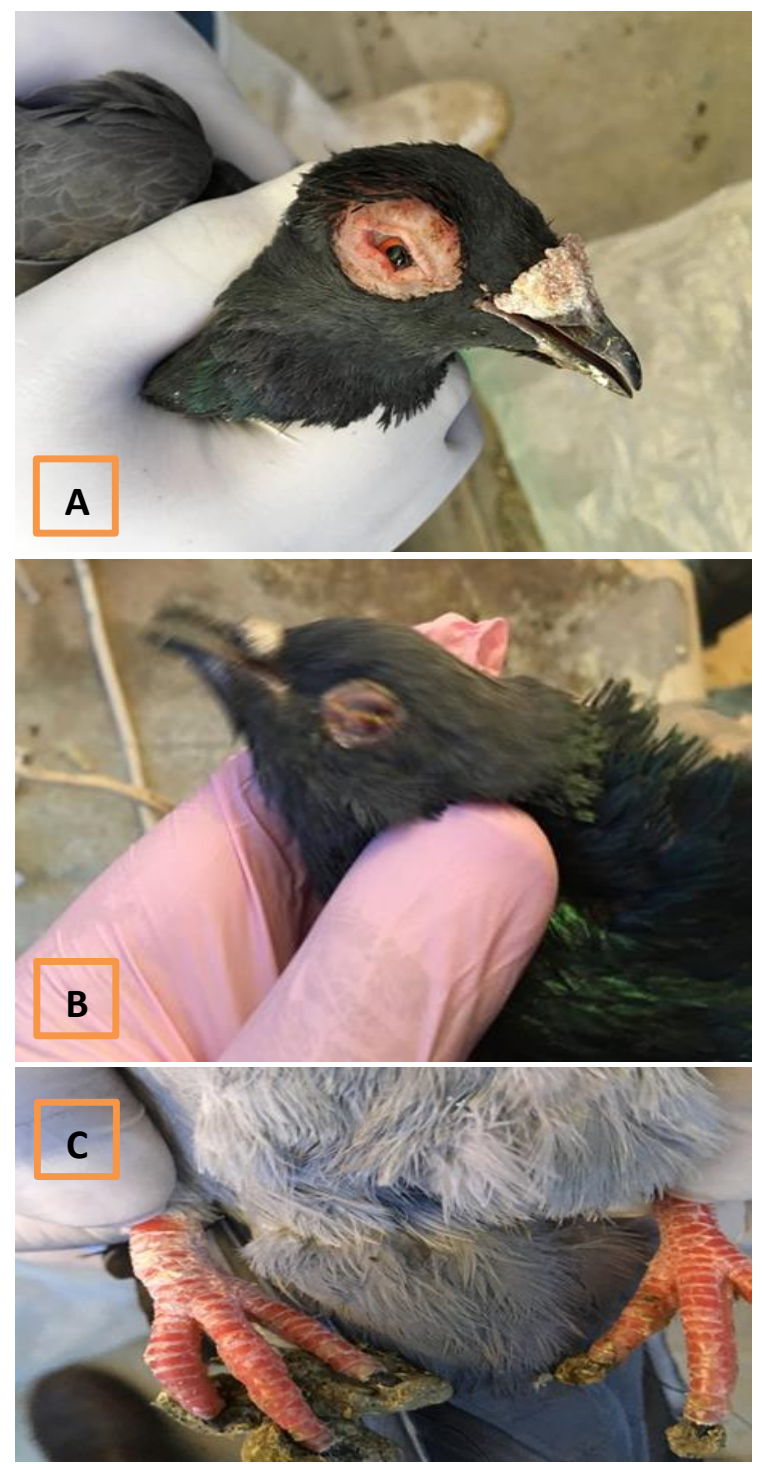

Figure 1. Conjunctivitis in feral (A) and domestic pigeons (B). Subcutaneous hemorrhagic of legs in domestic pigeons challenged with influenza virus subtype H9N2 (C).

\section{Histopathological findings}

\section{Pathological changes in trachea and lung}

The results of the histopathological examination on pigeons inoculated orally or intranasally with AIV indicated obvious pathological lesions accompanied by moderate to severe inflammation. These results revealed that there were clear pathological changes in lung some histological changes observed had parenchyma, ranging from moderate to severe multifocal necrosis diffused in the lung parenchyma. Also, infiltration with mononuclear inflammatory cells was detected in some lung areas associated with mild to severe inflammation (Figure 2). Additionally, some lung tissue exhibited clear edema and hemorrhage associated with severe congestion, degeneration and necrosis in the lung parenchyma (Figure 2). Furthermore, severe inflammatory cell infiltration was observed in the edges of lung parenchyma with clear degeneration and necrosis. Histological examination also showed alveolar damage with secretions containing blood, cell debris, and inflammatory cells.

There was obvious multifocal damage and desquamation of the pseudostratified columnar epithelium of the trachea of infected birds with AIV. Also, degeneration of mucosal gland tissue extended to the submucosa was observed. Furthermore, clear desquamation of epithelial cells into the luminal space was observed and associated with hemorrhage. The histological changes in parenchymal tissue of lung showed obvious damage to vascular endothelial cells and micro-thrombosis.

In addition to the abovementioned findings, damage and severe inflammation of lung parenchyma and bronchi accompanied by edema and hemorrhage were observed in group B (Figure 3). There was an obvious degeneration and desquamation of the pseudostratified columnar epithelium of trachea as well as clear degeneration of mucous glands. Also, some areas of the tracheal ring showed severe damage and hypertrophy in chondrocytes.

\section{Pathological changes of liver and intestine}

The pathological changes in liver (Figure 4) and intestines (Figure 5) revealed a mild to moderate inflammation and local necrosis close to the hepatic veins, whereas in intestine, these changes were observed in the submucosa.

\section{virus}

\section{Re-isolation and identification of the challenge}

The influenza virus (H9N2) was re-isolated from all tissue samples and cloaca swabs collected from pigeons with clinical signs in different groups. The re-isolated virus was detected by HA and identified by HI. 

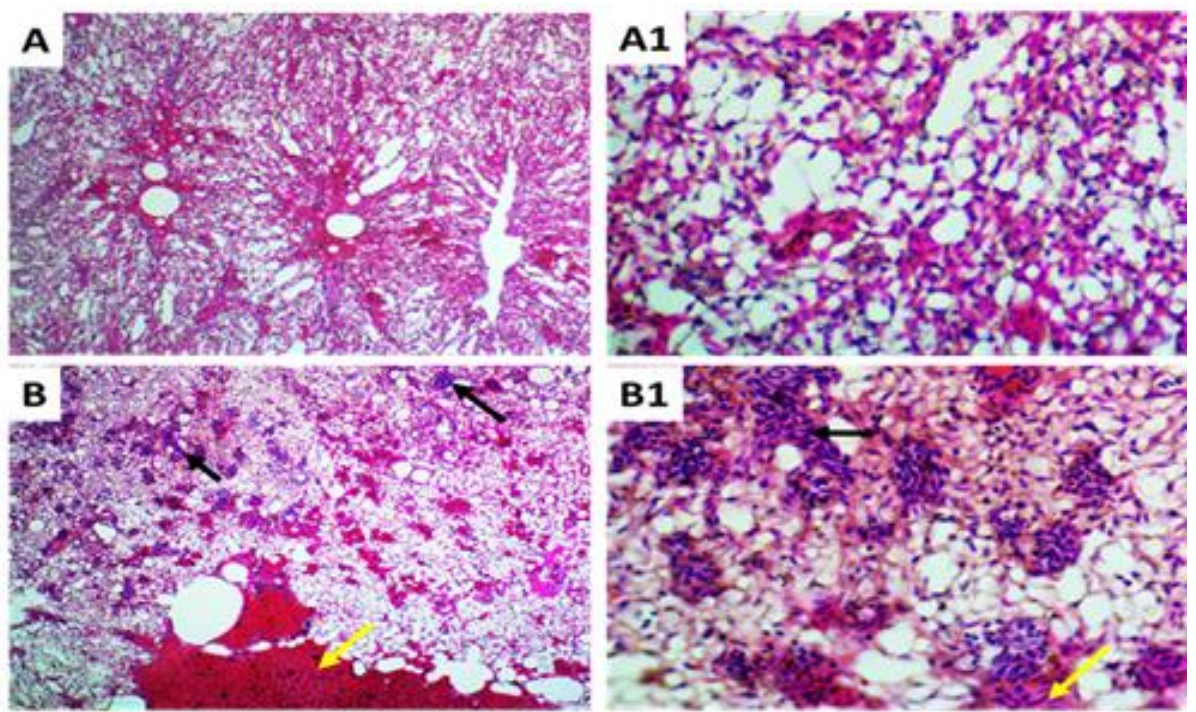

Figure 2. Photomicrographs of lung tissues of pigeons infected with influenza virus (H9N2). A and A1: The normal lung tissue. B and B1: The local infiltration of inflammatory cells represented by black arrows, whereas yellow arrows indicated the congestion and hemorrhage in alveoli (A and B at 10X; A1 and B1 at 40X) (H\&E).
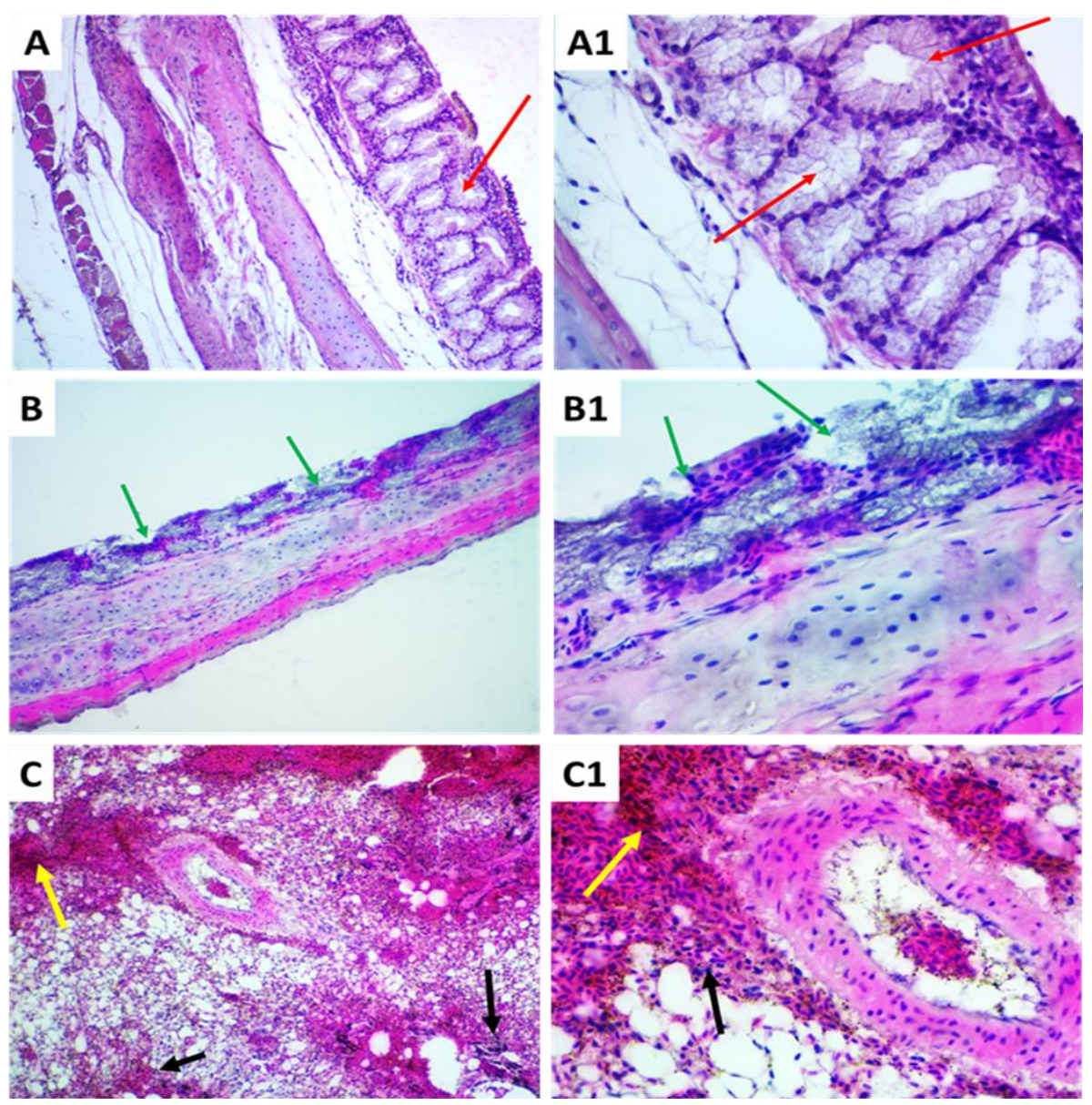

Figure 3. Photomicrographs of trachea and lung of pigeons infected with avian influenza virus (H9N2). A and A1: Normal trachea, simple alveolar mucous glands (red arrows). B and B1: Clear shrinkage and degeneration in the epithelium and mucous gland in the trachea (green arrows). $\mathrm{C}$ and $\mathrm{C} 1$ : The pathological changes exhibited in bronchi and lung parenchyma accompanied by severe infiltration of inflammatory cells (black arrows) and severe hemorrhage and edema (yellow arrows). (A, B, C at 10X; A1, B1, C1 at 40X) (H\&E). 

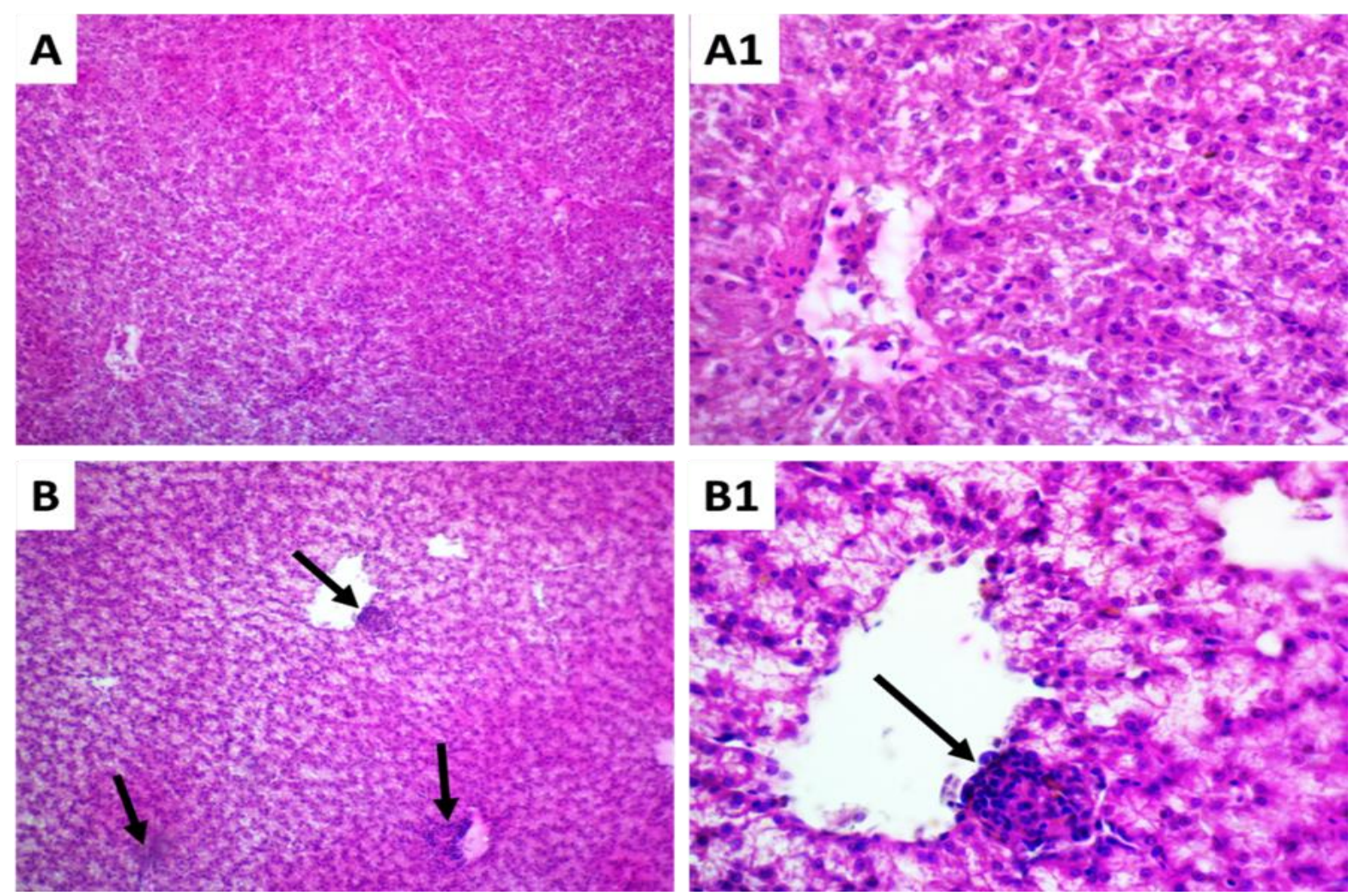

Figure 4. Photomicrographs of liver of pigeons infected with avian influenza virus (H9N2). A and A1: Normal liver. B and B1: Focal necrosis and infiltration of the inflammatory cells (black arrows) (A and B at 10X; A1 and B1 at 40X) (H\&E).
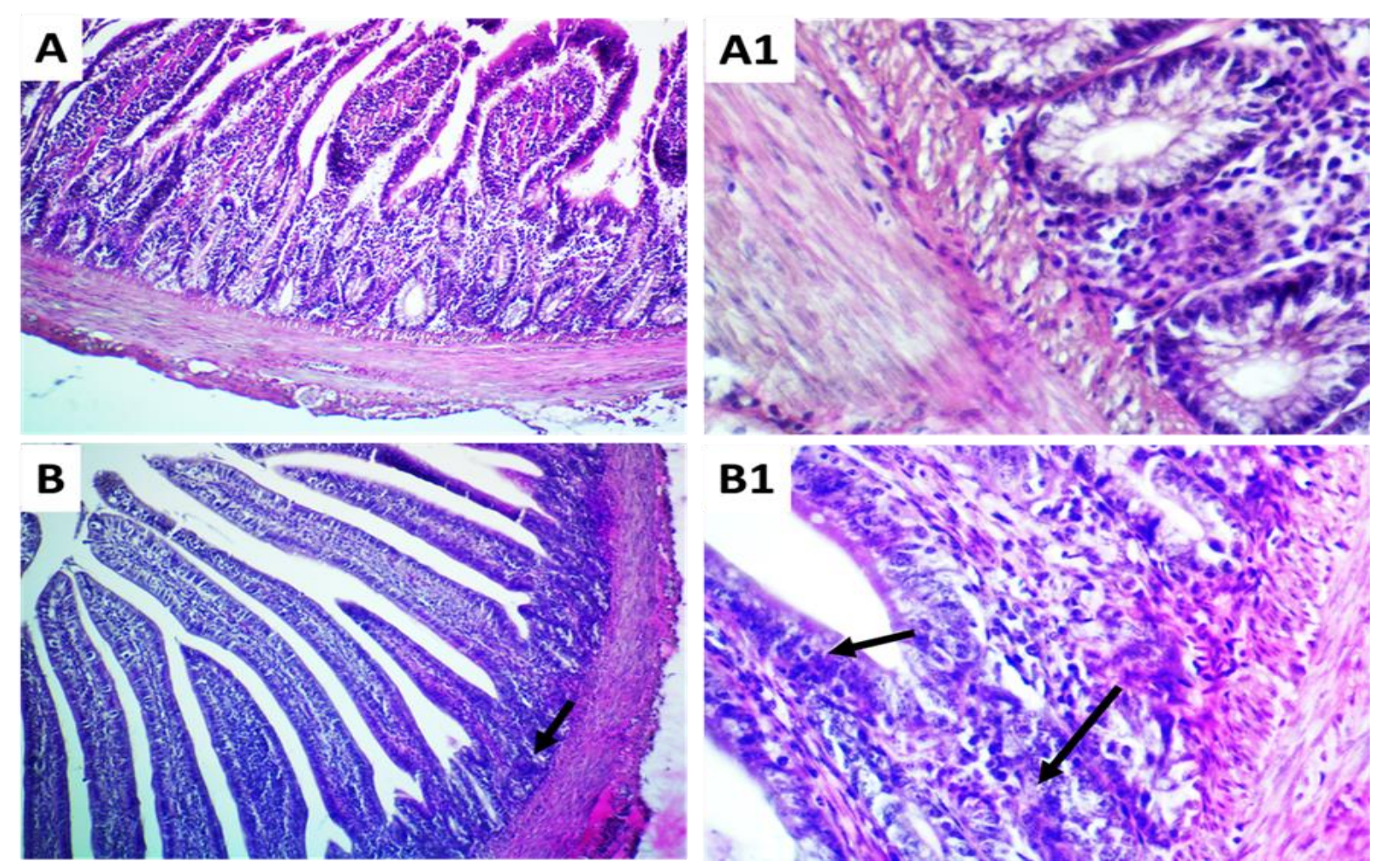

Figure 5. Photomicrographs of the intestine of pigeons infected with the avian influenza virus (H9N2). A and A1: Normal intestine. B and B1: Infiltration of the inflammatory cells (black arrows) (A and B at 10X, A1 and B1 at 40X) (H\&E). 


\section{DISCUSSION}

Influenza virus subtype H9N2 affects a broad spectrum of species including birds and mammals (Nagy et al., 2017). In poultry, it was reported to cause mild respiratory and digestive infection, but it may cause asymptomatic infections in other birds (Kandeil et al., 2017). Recent studies showed that co-circulation of other avian viruses like $\mathrm{H} 5 \mathrm{~N} 1$ and $\mathrm{H} 9 \mathrm{~N} 2$ in poultry farming and live bird markets had increased the risk of human exposure, resulting in complications of the epidemiological situation and raising a concern for potential emergence of new influenza A virus pandemic due to antigenic shift and drift resulted from gene exchange of the fragmented genome in case of mixed infection of the host with two subtypes of influenza virus type A (Kim, 2018). In Iraq, H9N2 is circulating among poultry farms (Khamas, 2008; AbdulSada, 2015; Kraidi et al., 2017; Hussein, 2019) and was serologically detected in pigeons (AL-Attar et al., 2008). The titer of hyperimmune serum in this test appeared as $2^{16} \mathrm{HIU} / 0.1 \mathrm{ml}$ of stock serum. The above-mentioned findings are mentioned by other researchers (Xu et al., 2018).

\section{Clinical signs}

The current study did not show any mortality rate among experimentally infected pigeons but only mild and moderate clinical signs. Abolnik (2014) mentioned that a very small number of pigeons infected with either HPAIV or LPAIV died in 22 different studies worldwide since 1944. Viruses such as H9N2 were proved to cause considerable morbidity but low or no mortality (Abolink, 2014; Hussein, 2019). Some other studies mentioned that ducks, gulls, starlings, and pigeons were less susceptible to AIV and displayed few or no clinical signs (MacLachlan and Dubovi, 2011). Generally, clinical signs appeared less in groups $\mathrm{A}$ and $\mathrm{B}$ compared to $\mathrm{C}$ and $\mathrm{D}$. This may be attributed to vaccination of groups A and B with the H9N2 vaccine. It is well known that vaccination can reduce the severity of infection but cannot prevent it (Ebrahimi et al., 2011; Bahari et al., 2015). A few cases of conjunctivitis were recorded in both domesticated and wild pigeons. This result agreed with the findings obtained by Kaleta and Honicke (2004) who reported one case of conjunctivitis out of 11 experimentally infected pigeons with the influenza virus. The clinical signs in infected pigeons of the present study were similar to those appeared in experimentally infected broiler chickens with H9N2 isolated from an outbreak in Iran. Field and experimentally infected birds showed similar clinical signs including sneezing, coughing and depression (Nili and Asasi, 2003). Similar findings were reported by another study in China (Sun and Liu, 2015). Experimental infection in broiler chickens using H9N2 and LaSota NDV vaccine revealed the same abovementioned clinical signs (Ellakany et al., 2018). Signs related to enteric infection with H9N2 such as greenish diarrhea and respiratory signs were also reported by (Tolba et al., 2017) in pigeons of Egyptian commercial farms and live birds market during winter of 2015-2016. The same authors mentioned the infection of humans with both H5N1 and H9N2. In another study in Pakistan, sneezing, nasal discharge, and other respiratory signs were reported in different species of birds including sparrows, chickens, jungle fowl, and quails infected directly or by contact with the virus. These clinical signs were observed 2 to 5 days PI (Iqbal et al., 2013).

\section{Antibody immune response}

All pigeons in the present study were subjected to antibody screening against AIV before starting vaccination and challenge with the virus. The pre-vaccination antiAIV antibody ranged from $152.83 \pm 42.01$ to $337.00 \pm$ 150.76; indicating the exposure of such birds to AIV somewhere or somehow. The study conducted by Turner et al. (2017) on the live bird markets in Bangladesh showed that H9N2 viruses were detected at high frequencies (76-100\%) in chickens, pigeons, and quail, while $9 \%$ of samples collected from ducks were positive for $\mathrm{H} 9 \mathrm{~N} 2$.

The presence of negative serum samples to AIV in pigeons might indicate the inexposure of such birds to AIV. The possibility of the presence of unexposed pigeons to AIV was reported by many studies. Mohammadi et al. (2010) found that $34 \%$ of serum samples collected from pigeons were positive for H9N2 antibodies. Tolba et al. (2018) detected antibodies against H9N2 in $6.5 \%$ of serum samples collected from pigeons. Serum samples collected from pigeons in Northern Saudi Arabia were negative for antibodies against $\mathrm{H} 3, \mathrm{H} 5$, and $\mathrm{H} 9$ serotypes of AIV (Alkhalaf, 2010). In a study conducted in Mosul province of Iraq, ELISA and HI tests were used for the detection of AIV antibodies in pigeons and starlings (AL-Attar et al., 2008). The results showed that $81.8 \%$ of pigeons were positive to AIV H9N2 antibodies when their sera were tested by ELISA, whereas, $50 \%$ of the same serum samples were positive when tested by the HI test. In addition, the serum samples collected from starlings were negative for AIV H9N2 antibodies and the birds did not show any clinical signs of influenza. The same authors concluded that pigeons can be infected with AIV subtype 
H9N2 and they may play an important role in AIV spreading as natural carriers.

Both groups vaccinated with inactivated H9N2 (A and $\mathrm{B})$ showed a significant increase $(\mathrm{P}<0.05)$ in AIV antibodies compared to antibody levels in the same groups before vaccination. Post-challenge AIV antibody levels showed a significant increase compared to postvaccination AIV antibody levels. Increased antibody levels in vaccinated groups (A and B) with inactivated H9N2 significantly differed from the antibody level of challenged but un-vaccinated groups (C and D). The increase in antibody levels of $\mathrm{C}$ and $\mathrm{D}$ groups can be attributed to the effects of challenge virus and might be also attributed to pre-exposure of birds to circulating H9N2 before challenge (Quinn et al., 2011).

The present study demonstrated that pigeon vaccination with $\mathrm{H} 9 \mathrm{~N} 2$ inactivated vaccine did not prevent the infection with the local isolate of H9N2. All challenged groups showed clinical signs of influenza virus infection, and the virus was detected by conventional RTPCR and by real-time RT-PCR (unpublished data). Furthermore, the virus was re-isolated from samples collected from challenged pigeons and identified by the HI test. Generally, the challenge virus was detected for longer periods of time in samples collected from unvaccinated groups compared to vaccinated groups and this might be attributed to immune responses and high antibody titers induced in vaccinated groups after challenge with live H9N2 virus that lead to the earlier clearance of the virus from infected birds (Quinn et al., 2011). Similar findings were reported in Iran when the inactivated H9N2 vaccine did not completely prevent the experimental infection with a field isolate of AIV subtype H9N2 in quails (Ebrahimi et al., 2011).

Several commercial AIV vaccines based on strains isolated during the late $20^{\text {th }}$ century were widely used in domestic poultry (Sun et al., 2012). However, some studies showed that H9N2 viruses were isolated from vaccinated chicken flocks, hence some vaccines did not provide complete protection against viral infection (Bahari et al., 2015; Shen et al., 2015).

Partial protection against circulating H9N2 induced by local H9N2 inactivated vaccine was also reported in Korea (Lee et al., 2011). Accordingly, the selection of suitable local isolate and strain for vaccine production against H9N2 LPAI is recommended (Sun et al., 2012). Mutations and inter and intra-reassortment are considered as factors affecting the ability of a vaccine to protect against AIV H9N2. These factors might be associated with the emergence of new virus strains with new biological features (Ashraf et al., 2017).

\section{Histopathology}

The pathogenicity of AIVs in pigeons and the vulnerability of pigeons for various subtypes of avian influenza have investigated in some studies (Yamamoto et al 2011; Liu et al., 2015). Furthermore, the ability of pigeons in being carrier and reservoir for these viruses has been studied (Liu et al., 2007). However, there is little literature on the pathophysiological effects of AIV H9N2 on pigeons. In the current study, H9N2 subtype was found to cause severe tracheitis and pneumonia as well as mild pathological changes in liver and intestine of infected pigeons. There are similarities between these results and the histopathological observations reported in chickens infected with AIV H9N2 (Hassan et al., 2017; Arafat et al., 2018).

The presence of such pathological changes as well as direct pathogenicity in the trachea and lung indicate that H9N2 has tissue tropism for these organs (Halblolvarid et al., 2004). It can also be assumed that the presence of multifocal necrosis in the liver indicates a potential systemic viral infection with the H9N2 (Bano et al., 2003). In this study, the most important pathological changes were widespread hemorrhages with the massive edema and congestion in the lung parenchyma. Also, there was prominent degeneration in the alveolar epithelium. The histopathologic findings obtained in this study are in line with the observations of other studies on Japanese quail (Ebrahimi et al., 2010; Mehrabadi et al., 2018) and in Muscovy duck (Wang et al., 2019) infected with AIV H9N2.

The severe pathological changes observed in the trachea and lungs could be attributed to the presence of SAa2, $6 \mathrm{Gal}$ receptors in the epithelial surfaces of the pharynx, trachea and bronchial tree of pigeons, which is the same receptors found for human influenza viruses (Liu et al., 2009). Although some studies reported that pigeons are less or not susceptible to AIV such as the H5N1serotypes (Liu et al., 2007), the present study demonstrated the pathophysiological aspects of H9N2 in pigeons.

\section{CONCLUSION}

The influenza virus (H9N2) can cause mild infection in wild and domestic pigeons that might facilitate the transmission of H9N2 to other birds. The mixed infection of pigeons with different subtypes of the influenza virus 
may increase the risk of generation of new virulent subtypes. Further research should be conducted to monitor the virus and to investigate the interactions between the H9N2 and other serotypes in pigeons. Furthermore, commercial vaccines, regardless of the level of the antibody obtained, did not prevent the infection with serotype H9N2 but reduce its virulence.

\section{DECLARATIONS}

\section{Acknowledgments}

The authors would like to acknowledge the College of the Veterinary Medicine University of Diyala for logistic supports. The authors also acknowledge all the staff of the microbiology department and molecular biology laboratory for timely help with guidance and support. The present study received no financial support.

\section{Authors' contributions}

Ahmed Raad Rasheed designed the study and collected the samples from the infected Pigeons. Karim Sadun Al-Ajeeli and Amer Khazaal Al-Azawy were involved in editing the manuscript and analyzing the data. All authors read and approved the final manuscript.

\section{Competing interests}

The authors declare that they have no competing interests.

\section{REFRENCES}

Abdelwhab EM and Abdel-Moneim AS (2015). Epidemiology, ecology and gene pool of influenza A virus in Egypt: will Egypt be the epicentre of the next influenza pandemic. Virulence, 6: 6-18. DOI: https://doi.org/10.4161/21505594.2014.992662.

Abdul-Sada KM (2015). Surveillance of influenza A/ H5, H7, H9 viral subtypes in domestic and wild birds at many geographical regions of Iraq. International Journal of Advanced Research, 3: 170176. Available at: http://www.journalijar.com

Abolink C (2014). A current review of avian influenza in pigeons and doves (Columbidae). Veterinary Microbiology, 170: 181-196. DOI: https://doi.org/10.1016/j.vetmic.2014.02.042

AL-Attar MY, Danial FA and Al-Baroodi SY (2008). Detection of antibodies against avian influenza virus in wild pigeons and starlings. Journal of Animal and Veterinary Advances, 7(4): 448$449 . \quad$ Available at: http://medwelljournals.com/abstract/?doi=javaa.2008.448.449 .

Alkhalaf AN (2010). Field investigation on the prevalence of avian influenza virus infection in some localities in Saudi Arabia. Pakistan Veterinary Journal, 30: 139-142.

Arafat N, Eladi AH, Marghani BH, Saif MA and El-Shafei RA (2018). Enhanced infection of avian influenza virus H9N2 with infectious laryngotracheitis vaccination in chickens. Veterinary microbiology, 219, 8-16. DOI: https://doi.org/10.1016/j.vetmic.2018.04.009 .

Arai Y, Ibrahim MS, Elgendy EM, and Daidoji T (2019). Genetic compatibility of reassortment between avian $\mathrm{H} 5 \mathrm{~N} 1$ and $\mathrm{H} 9 \mathrm{~N} 2$ influenza viruses with higher pathogenicity in mammals. Journal of Virology, 93(4):1-17.DOI: https://doi.org/10.1128/jvi.01969-18.

Ashraf MU, Mahmood MS, Rafique A, Abbas RZ, Iqbal Z, Younas M and Ishaq MU (2017). Factors responsible for the continuous persistence and evolution of low pathogenic avian influenza virus (H9N2). World's Poultry Science Journal, 73(4): 791-802. DOI: https://doi.org/10.1017/s004393391700071x .

Bahari P, Pourbakhsh SA, Shoushtari H, and Bahmaninejad MA (2015). Molecular characterization of $\mathrm{H} 9 \mathrm{~N} 2$ avian influenza viruses isolated from vaccinated broiler chickens in northeast Iran. Tropical Animal Health and Production. 47:1195-1201.DOI: https://doi.org/10.1007/s11250-015-0848-X .

Bancroft JD and Gamble M (2008). Theory and practice of histological techniques, Elsevier health sciences. 6th Edition, Churchill Livingstone, Elsevier, China.

Bano S, Naeem K and Malik SA (2003). - Evaluation of pathogenic potential of avian influenza virus serotype H9N2 in chickens. Avian Diseases, 47: 817-822.DOI: https://doi.org/10.1637/0005-208647.s3.817.

Durrani UF, Khan M and Ahmad SS (2008). Comparative efficacy (sedative and anaesthetic) of detomidine, ketamine and detomidineketamine cocktail in pigeons (Columba livia). Pakistan Veterinary Journal, 28 (3): 115-118.

Ebrahimi SM, Nili H and Sohrabi N (2010). Histopathological evaluation of A/Chicken/iran/339/02 (H9N2), an Iranian field isolate of influenza virus, on Japanese quail (Coturnix coturnix japonica). World Applied Science Journal, 9: 226-229.

Ebrahimi SM, Ziapour S, Tebianian M, Dabaghian M and Mohammadi M (2011). Study of infection with an Iranian field-isolated H9N2 avian influenza virus in vaccinated and unvaccinated Japanese quail. Avian Diseases, 55: 195-200. DOI: https://doi.org/10.1637/9714-953811-digest.1 .

Ellakany HF, Gado AR, Elbestawy AR, El-Hamid HAS, Hafez HM, ElHack MEA, and Saadeldin, IM (2018). Interaction between avian influenza subtype H9N2 and Newcastle disease virus vaccine strain (LaSota) in chickens. BMC veterinary research, 14(1): 358-368. DOI: https://doi.org/10.1186/s12917-018-1689-4 .

Gomaa MR, Kayed AS, Elabd MA, Zeid DA, Zaki SA, El Rifay AS, Sherif LS, McKenzie PP, Webster RG, Webby RJ, er al. (2015). Avian influenza A $(\mathrm{H} 5 \mathrm{~N} 1)$ and $\mathrm{A}(\mathrm{H} 9 \mathrm{~N} 2)$ seroprevalence and risk factors for infection among Egyptians: a prospective, controlled seroepidemiological study. Journal of Infectious Diseases, 211:1399_1407. DOI: https://doi.org/10.1093/infdis/jiu529 .

Halblolvarid M, Sohraby HI, Pourakhsh S and Gholami M (2004). Histopathological study of intratracheally inoculated A/Chicken/Iran/259/1998 (H9N2) influenza virus in Chicken. Archives of Razi Institute, 58: 51-62.

Hassan KE, Ali A, Shany SA and El-Kady MF (2017). Experimental coinfection of infectious bronchitis and low pathogenic avian influenza H9N2 viruses in commercial broiler chickens. Research in Veterinary Science, 115: 356-362. DOI: https://doi.org/10.1016/j.rvsc.2017.06.024

Horwitz MS, and Scharff MD (1969). The production of Antiserum against Viral Antigens. In: Fundamental Techniques in Virology, Academic press, p. 253

Hussein MA (2019). Studies on isolation, identification, pathotyping with sequencing and genotyping of most occurrence strains of Newcastle Virus and Avian Influenza virus in Karbala province. Ph.D. Thesis submitted to the College of Veterinary Medicine University of Baghdad.

Imai M, Herfst S, Sorrell EM, Schrauwen EJ, Linster M, De Graaf M, Fouchier RA and Kawaoka Y (2013). Transmission of influenza A/H5N1 viruses in mammals. Virus Research, 178: 15-20. DOI: https://doi.org/10.1016/j.virusres.2013.07.017.

Iqbal M, Yaqub T, Mukhtar N, Shabbir MZ, and McCauley JW (2013). Infectivity and transmissibility of $\mathrm{H} 9 \mathrm{~N} 2$ avian influenza virus in 
chickens and wild terrestrial birds. Veterinary Research, 44(1): 100110. DOI: https://doi.org/10.1186/1297-9716-44-100 .

Kaleta EF, Honicke A (2004). Review of the literature on avian influenza A viruses in pigeons and experimental studies on the susceptibility of domestic pigeons to influenza A viruses of the haemagglutinin subtype H7. Deutsche tierärztliche Wochenschrift, 111: 453-484.

Kandeil A, El-Shesheny R, Maatouq A, Moatasim Y, Cai Z, McKenzie P, Webby R, Kayali G and Ali MA (2017). Novel reassortant H9N2 viruses in pigeons and evidence for antigenic diversity of H9N2 viruses isolated from quails in Egypt. Journal General Virology, 98: 548-562. DOI: https://doi.org/10.1099/jgv.0.000657.

Kausar A, Anwar S, Siddique N, Ahmed S, and Dasti JI (2018). Prevalence of Avian influenza H9N2 Virus among Wild and Domesticated Bird Species across Pakistan. Pakistan Journal of Zoology, 50(4): 1347-1354. DOI: https://doi.org/10.17582/journal.pjz/2018.50.4.1347.1354 .

Khamas E (2008). Avian influenza (H9N2) outbreak In Iraq. Iraqi Journal of Veterinary Science, 32: 223-230.

Killian ML (2008). Hemagglutination assay for avian influenza virus. In Avian influenza virus, Humana Press, pp.47-52. DOI: https://doi.org/10.1007/978-1-59745-279-3 7 .

Kim SH (2018). Challenge for One health: co-circulation of zoonotic H5N1 and H9N2 avian influenza viruses in Egypt. Viruses, 10 (3): 121-128. DOI: https://doi.org/10.3390/v10030121.

Kraidi QA, Langeroudi AG, Madadgar O and Karimi V (2016). Prevalence of AIV subtype H9 among poultry with respiratory signs in Iraq. Bulgarian Journal of Veterinary Medicine, 20 (4): 367-376. DOI: https://doi.org/10.15547/bjvm.1022.

Kraidi QA, Madadgar O, Ghalyanchi Langeroudi A and Karimi V (2017). Genetic analysis of H9N2 avian influenza viruses circulated in broiler flocks: a case study in Iraq in 2014-2015. Virus Genes, 53: 205-214. DOI: https://doi.org/10.1007/s11262-016-1407-x .

Lee DH, Bahl J, Torchetti MK, Killian ML, Ip HS, DeLiberto TJ, and Swayne DE (2016). Highly pathogenic avian influenza viruses and generation of novel reassortants, United States, 2014-2015. Emerging Infectious Diseases, 22:1283-1285. DOI: https://doi.org/10.3201/eid2207.160048.

Lee YN, Lee DH, Park JK, Lim TH, Young HN, Yuk SS, Lee YI, Mo IP (2011).Isolation and characterization of a novel H9N2 influenza virus in Korean native chicken farm. Avian Disease, 55:724-7. DOI: https://doi.org/10.1637/9925-977411-digest.1 .

Liu Y, Han NC, Wang X, Lin J, Ma M, Shu Y, Zhou J, Yang H, Liang Q and Guo $C$ (2009). Influenza A virus receptors in the respiratory and intestinal tracts of pigeons. Avian Pathology, 38, 263-266. DOI: https://doi.org/10.1080/03079450903055363.

Liu Y, Yang Z, Wang X, Chen J, Yao J, Song Y and Pan J (2015). Pigeons are resistant to experimental infection with H7N9 avian influenza virus. Avian Pathology, 44(5): 342-346. DOI: https://doi.org/10.1080/03079457.2015.1055235.

Liu Y, Zhou J, Yang H, Yao W, Bu W, Yang B, Song W, Meng Y, lin J and Han C (2007). Susceptibility and transmissibility of pigeons to Asian lineage highly pathogenic avian influenza virus subtype H5N1. Avian Pathology, 36: 461-465. DOI: https://doi.org/10.1080/03079450701639335.

MacLachlan NJ and Dubovi EJ (2011). Orthomyxoviridae. In Fenner's Veterinary Virology. 4th Edition. Academic Press, Elsevier Publication. pp. 353-370.

Mehrabadi MHF, Bahonar A, Mirzaei K, Molouki A, Ghalyan Chilangeroudi A, Ghafouri SA, Tehrani F and Lim SHE (2018). Prevalence of avian influenza (H9N2) in commercial quail, partridge, and turkey farms in Iran, 2014-2015. Tropical Animal Health and Production, 50: 677-682. DOI: https://doi.org/10.1007/s11250-017-1438-x.

Mohamed N, Mohamed S, Kandeil A, AL-Zubaidy IAH, Kayali G and Ali M.A (2018). Genetic and antigenic characterization of avian influenza H9N2 viruses during 2016 in Iraq. Open Veterinary Journal, 9(2): 164-171. DOI: https://doi.org/10.4314/ovj.v9i2.12.

Mohammadi, A., Masoudian, M., Nemati, Y., and Seifi, S. (2010). Serological and RT-PCR assays for detection of avian influenza of domestic pigeons in Kavar area (Fars province, Iran). Bulgarian Journal of Veterinary Medicine, 13(2): 117-121.

Mostafa A, Abdelwhab EM, Mettenleiter TC, and Pleschka S (2018). Zoonotic potential of influenza A viruses: a comprehensive overview. Viruses, 10(9): $497 . \quad$ DOI.https://doi. org/10.3390/v10090497

Nagy A, Mettenleiter TC, and Abdelwahab EM (2017). A brief summary of the epidemiology and genetic relatedness of avian influenza H9N2 virus in birds and mammals in the Middle East and North Africa. Epidemiology and Infection, 145:3320-3333. DOI: https://doi.org/10.1017/s0950268817002576.

Nili H, and Asasi K (2003). Avian influenza (H9N2) outbreak in Iran. Avian Diseases, 47: 828-831. DOI: https://10.1637/0005-208647.s3.828.

Quinn PJ, Markey BK, Leonard FC, Hartigan P, Fanning S and Fitzpatrick EI (2011). Veterinary microbiology and microbial disease. The Veterinary Journal, 165 (3): 333. DOI: https://doi.org/10.1016/s1090-0233.

Reed LJ and Muench H (1938). A simple method of estimating fifty percent endpoints 12. American Journal of Epidemiology, 27(3): 493-497. DOI: https://doi.org/10.1093/oxfordjournals.aje.a11840 .

Shehata AA, Parvin R, Sultan H, and Halami MY (2015). Isolation and full genome characterization of avian influenza subtype H9N2 from poultry respiratory disease outbreak in Egypt. Virus Genes, 50 (3): 389-400. DOI: https://doi.org/10.1007/s11262-015-1188-7.

Shen HQ, Yan ZQ, Zeng FG, Liao CT, and Zhou QF (2015). Isolation and phylogenetic analysis of hemagglutinin gene of H9N2 influenza viruses from chickens in South China from 2012 to 2013. Journal of Veterinary Science 16:317-324.DOI: https://doi.org/10.4142/jvs.2015.16.3.317.

Sun Y and Liu J (2015). H9N2 influenza virus in China: a cause of concern. Protein and cell, 6(1): 18-25. DOI: https://doi.org/10.1007/s13238-014-0111-7.

Sun Y, Pu J, Fan L, Sun H, Wang J, Zhang YI, Liu L and Liu J (2012). Evaluation of the protective efficacy of a commercial vaccine against different antigenic groups of H9N2 influenza viruses in chickens. Veterinary Microbiology, 156:193-199. DOI: https://doi.org/10.1016/j.vetmic.2011.10.003.

Tolba HMN, Rasha MM, Abou Elez IE and Heba AA (2018). Molecular identification of avian influenza virus subtypes H5N1 and H9N2 in birds from farms and live bird markets and in respiratory patients. Peer Journal, (6): 5473. DOI: https://doi.org/10.7287/peerj.5473v0.1/reviews/4.

Turner JC, Feeroz MM., Hasan MK, Akhtar S, Walker D, Seiler P, and Krauss S (2017). Insight into live bird markets of Bangladesh: an overview of the dynamics of transmission of $\mathrm{H} 5 \mathrm{~N} 1$ and $\mathrm{H} 9 \mathrm{~N} 2$ avian influenza viruses. Emerging microbes and infections, 6(1): 18. DOI: https://doi.org/10.1038/emi.2016.142 .

Wang C, Wang Z, Ren X, Wang L, Li C, Sun Y, Wang M, Tong Q, Sun $\mathrm{H}$ and Pu J (2019). Infection of chicken H9N2 influenza viruses in different species of domestic ducks. Veterinary microbiology, 233: 1-4. DOI: https://doi.org/10.1016/j.vetmic.2019.04.018 .

Webster RG, Cox N and Stöhr K (2002) WHO Manual on Animal Influenza Diagnosis and Surveillance. Available at: http://www.who.int/csr/resources/publications/influenza/whocdscsr ncs20025rev.pdf.

Williams JE (1980). Micro test methodology. In: Isolation and Identification of Avian pathogens 2nd Edition .S. B. Hitchner. C. H. Domermuth. H. G. Purchase and J. E. Williams (Editors). American Association of Avian pathologiss College Station., pp. 136 - 140.

Xu C, Ye H, Qiu W, Lin H, Chen Y, Zhang H and Liao M (2018). Phylogenetic classification of hemagglutinin gene of H9N2 avian 
Rasheed et al., 2020

influenza viruses isolated in China during 2012-2016 and evaluation of selected candidate vaccine strains. Poultry Science, 97(9): 3023-3030. DOI: https://doi.org/10.3382/ps/pey154 .

Xu W, Shao Q, Zang Y, Guo Q, Zhang Y and Li Z (2015). Pigeon RIG-I function in innate immunity against H9N2 AIV and IBDV. Viruses, 7: 4131-4151. DOI: https://doi.org/10.3390/v7072813.

Yamamoto Y, Nakamura K, Yamada M and Mase M (2011). Limited susceptibility of pigeons experimentally inoculated with H5N1 highly pathogenic avian influenza viruses. Journal of Veterinary
Medical
Science,
$74 \quad$ (2):
205-208.
DOI:

https://doi.org/10.1292/jvms.11-0312. 